Summer 2013

\title{
Parenthood Status and Compensation in Law Practice
}

\author{
Nancy Reichman \\ University of Denver, nancy.reichman@du.edu \\ Joyce Sterling \\ University of Denver College of Law, jsterling@law.du.edu
}

Follow this and additional works at: https://www.repository.law.indiana.edu/ijgls

Part of the Civil Rights and Discrimination Commons, Labor and Employment Law Commons, Law and Gender Commons, Law and Society Commons, and the Legal Profession Commons

\section{Recommended Citation}

Reichman, Nancy and Sterling, Joyce (2013) "Parenthood Status and Compensation in Law Practice," Indiana Journal of Global Legal Studies: Vol. 20 : Iss. 2 , Article 21.

Available at: https://www.repository.law.indiana.edu/ijgls/vol20/iss2/21

This Symposium is brought to you for free and open access by the Law School Journals at Digital Repository @ Maurer Law. It has been accepted for inclusion in Indiana Journal of Global Legal Studies by an authorized editor of Digital Repository @ Maurer Law. For more information, please contact rvaughan@indiana.edu.

\section{$\Psi$}

JEROME HALL LAW LIBRARY

INDIANA UNIVERSITY

Maurer School of Law
Bloomington 


\title{
Parenthood Status and Compensation in Law Practice
}

\author{
NANCY REICHMAN ${ }^{*}$ \& JOYCE STERLING ${ }^{\dagger}$
}

\begin{abstract}
This article asks how cultural frameworks of status influence the evaluation of performance including compensation and advancement of lawyers who were seven years into their practice. We borrow from the work on status expectations that goes beyond gender distinctions and assesses whether the concept of motherhood has a negative impact on assessment of female lawyers. Status expectations theory hypothesizes that mothers are valued less because they are less committed to the workplace and thus receive a motherhood penalty while men receive a fatherhood bonus in compensation decisions. Employing data from the After The JD study, we test the impact of parenthood on compensation decisions. Our analysis reveals that gender matters more than parenthood status in compensation. Thus we conclude that parenthood is not found to have a significant effect on credentials, orientation to work, or practice setting.
\end{abstract}

\section{INTRODUCTION}

The gender gap in compensation persists and grows, despite the increased representation of women in the legal profession over the last two decades. ${ }^{1}$ In the first-wave analysis of After the $J D(A J D)$, a

* Professor Nancy Reichman is Professor of Sociology and Criminology at University of Denver. of Law.

$\dagger$ Professor Joyce Sterling is Professor of Law at University of Denver, Sturm College

1. See generally Ronit Dinovitzer, Nancy J. Reichman \& Joyce S. Sterling, The Differential Valuation of Women's Work: A New Look at the Gender Gap in Lawyers' Incomes, 88 SOC. FORCES 819 (2009) [hereinafter Differential Valuation]; Nancy J. Reichman \& Joyce S. Sterling, Recasting the Brass Ring: Deconstructing and Reconstructing Workplace Opportunities for Women Lawyers, 29 CAP. U. L. REv. 923 (2002) [hereinafter Brass Ring]; Nancy J. Reichman \& Joyce S. Sterling, Sticky Floors, Broken

Indiana Journal of Global Legal Studies Vol. 20, Issue 2 (2013)

(C) Indiana University Maurer School of Law 
national longitudinal study of the career trajectories of lawyers who passed the bar in 2000 , we found a gender gap of nearly $\$ 6,000$ : the average salary for women was $\$ 90,527$ compared to the average of $\$ 96,486$ for men. ${ }^{2}$ In the second wave of the study and after seven years of practice, the gap is much larger, almost $\$ 20,000$, with women reporting an average salary of $\$ 94,145$ compared to the $\$ 114,426$ average for men. ${ }^{3}$ How can we make sense of the continuing increase in the income gap given the increased presence of women in the profession?

Although the literature is ripe with theoretical frameworks that differ in focus and nuance, in general we find three overarching explanations for gender disparities. One strand of research develops an economic model of discrimination that follows the work of Gary Becker. ${ }^{4}$ These explanations account for disparity by examining differences in the accumulation of human capital (e.g. hours worked, law school attended, and other accumulated attributes) and argue that women are more likely to invest in family than careers. ${ }^{5}$ Becker's classic "taste for discrimination" model suggests that employers' compensation decisions are related to their interest in attracting or avoiding certain groups of workers, a perspective influenced by prejudice or ignorance. ${ }^{6}$ Since discrimination is inherently inefficient, Becker believed that market competition would ultimately eliminate it. ${ }^{7}$

A second general category of explanation focuses on the "choices" women make to reduce work experience (time and effort). While some who follow this perspective focus on the pull of families, others more accurately recognize choice as mediated by workplace structures that are inhospitable to women. ${ }^{8}$ From this perspective, the choice to stay

Steps, and Concrete Ceiling in Legal Careers, 14 TEX. J. WOMEN \& L. 27 (2004) thereinafter Sticky Floors].

2. Differential Valuation, supra note 1 , at 828.

3. Joyce S. Sterling \& Nancy Reichman, Navigating the Gap: Reflections on 20 Years Researching Gender Disparities in the Legal Profession, 8(2) FLORIDA INTL. L.R. (Forthcoming 2013); RONIT DinOVITZER ET AL., AFTER THE JD II: SECOND RESUlTS FROM A NATIONAL STUDY OF LEGAL CAREERS (2009) [hereinafter AJD2].

4. See generally Gary S. BECKER, HuMAN CAPITAL: A THEORETICAL AND EMPIRICAL ANALYSIS WITH SPECIAL REFERENCE TO EDUCATION (3d ed. 1993).

5. See generally Jacob Mincer \& Solomon Polachek, Family Investments in Human Capital: Earnings of Women, 82 J. PoL. ECON. S76 (1974).

6. See generally Åsa Rosén, Search, Bargaining, and Employer Discrimination, $21 \mathrm{~J}$. LAB. ECON. 807 (2003).

7. See generally GARY S. BECKER, The ECONOMICS OF DisCRIMINATION (2d ed. 1971).

8. For evidence about how women are pushed out of the workplace, rather than exits simply being a matter of choice, see Joan C. Williams et.al., "Opt-Out" Or Pushed Out? How The Press Covers Work/Family Conflict, WORK LIFE LAW, UC HASTINGS COLLEGE OF THE LAW, 44, 48 (2006). 
home with children is always made within a context where women see more or less possibility for career advancement; women are "pushed" from work at the same time they are "pulled" toward home. ${ }^{9}$

A third strand of research investigates the role that "cultural superschema" play in the persistent inequalities that women face.10 Here, the focus is on the cultural constructions of performance that attach to particular statuses, e.g. gender, so that some groups are viewed as more or less worthy than others. ${ }^{11}$ As these cultural schemas profoundly influence the assessment of competence, commitment, and performance, they also create barriers to the advancement of workers who are culturally defined as less worthy. ${ }^{12}$ Theorists in this tradition provide an answer to why inequality and discrimination persist even when employers do not exhibit prejudicial attitudes. Consistent with status expectations, employers will prefer one status group-male lawyers in the present instance-over another because they perceive

9. For literature on choice, see generally ABA COMM'N ON WOMEN IN THE PROFESSION, THE UNFINISHED AGENDA: WOMEN AND THE LEGAL PROFESSION (2001); CYNTHIA FUCHS EPSTein et al., The Part-Time Paradox: Time Norms, Professional Life, Family and Gender (1999); KathleEN Gerson, Hard Choices: How Women Decide ABout Work, Career, AND Motherhood (1985); John HaGan \& FIona Kay, Gender in Practice: A Study of LaWyers' Lives (1995); JerRy A. Jacobs \& KathleEn Gerson, The Time Divide: WORK, Family, aNd GeNDER INEquality (2004); JoAN Williams, UNBENDing GENDER: WHY FAMILY AND WORK CONFLICT AND What to Do ABOUT IT (2000) [hereinafter UNBENDING GENDER]; Joan C. Williams et al., supra note 8; Michael Betz \& Lenahan O'Connell, Work Orientations of Males and Females: Exploring the Gender Socialization Approach, 59 Soc. INQUIRY 318 (1989); Denise D. Bielby \& William T. Bielby, She Works Hard for the Money: Household Responsibilities and the Allocation of Work Effort, 93 AM. J. Soc. 1031 (1988); Denise Del Vento Bielby \& William T. Bielby, Work Commitment, SexRole Attitudes, and Women's Employment, 49 AM. Soc. REv. 234 (1984); Margaret Mooney Marini et al., Gender and Job Values, 69 Soc. EDUC. 49 (1996); Christine Percheski, Opting Out? Cohort Differences in Professional Women's Employment Rates from 1960 to 2005, 73 AM. SoC. REV. 497 (2008); Brass Ring, supra note 1; Deborah L. Rhode, The "NoProblem" Problem: Feminist Challenges and Cultural Change, 100 YALE L.J. 1731 (1991); Carroll Seron \& Kerry Ferris, Negotiating Professionalism: The Gendered Social Capital of Flexible Time, 22 Work \& Occupations 22 (1995); Pamela Stone \& Meg Lovejoy, Fast Track Women and the "Choice" to Stay Home, 596 AnNALS AM. ACAD. POL. \& Soc. SCI. 62 (2004).

10. See generally Cecilia L. Ridgeway, Framed by Gender: How Gender InEquality PERSISTS IN THE MODERN WORLD (2011). For the original formulation of this theory, see generally JOSEPH BERGER ET AL., STATUS CHARACTERISTICS AND SOCIAL INTERACTION: AN EXPECTATION-STATES APPROACH (1977); David G. Wagner \& Joseph Berger, Expectations States Theory: An Evolving Research Program, in NEW DIRECTIONS IN CONTEMPORARY SOCIOLOGICAL THEORY 41 (Joseph Berger \& Morris Zelditch Jr. eds., 2002).

11. See Shelley J. Correll \& Stephen Benard, Biased Estimators? Comparing Status and Statistical Theories of Gender Discrimination, 23 ADVANCES GrouP PROCESSES 89 (2006) [hereinafter Biased].

12. See id. at 91. 
them as more competent and worthy. ${ }^{13}$ The evaluation of potential and actual performance becomes a "self-fulfilling prophesy" when certain status actors (male lawyers) are given more opportunities to participate and to demonstrate their competence in the workplace. When employers have higher performance expectations for men, they provide men with more opportunities to participate and excel in the workplace, and subsequently they are more likely to interpret men's performances to be superior to those of women. ${ }^{14}$ Status expectations theory also contributes to our understanding of double standards. ${ }^{15}$ Lower status actors (women) receive stricter scrutiny in task performance, and, regardless of their achievements, they are viewed as underperforming compared to high status actors.

\section{Motherhood Penalties, Fatherhood Bonuses-EvidenCe From PAST RESEARCH?}

This paper attempts to build on our understanding of how cultural frameworks of status influence the evaluation of performance and, thus, compensation and advancement. Importantly, over the last decade, the literature on status expectations has shifted attention away from a simple gender distinction to explore the concept of motherhood as an important status in its own right. ${ }^{16}$ Simply put, mothers are viewed as less status worthy and less competent than fathers. ${ }^{17}$ The association of mothers and fathers with a traditional gender division of labor leads to the assumption that fathers have a greater motivation and commitment to work, while mothers would prefer to stay home and take care of children. These role stereotypes become important "background" for assessments such that men may receive a "daddy bonus," 18 while women

13. Cf. John J. Donohue III \& James J. Heckman, The Law and Economics of Racial Discrimination in Employment: Re-Evaluating Federal Civil Rights Policy, 79 GEo. L.J. 1713 (1991). They have argued that discrimination is reinforced by cultural norms.

14. Biased, supra note 11 , at 107.

15. See generally Martha Foschi, Status Characteristics, Standards, and Attributions, in Sociological Theories in Progress: New Formulations 58 (Joseph Berger et al. eds., 1989).

16. See generally RIDGEwaY, supra note 10; Michelle J. Budig \& Melissa J. Hodges, Differences in Disadvantage: Variation in the Motherhood Penalty across White Women's Earnings Distribution, 75 AM. Soc. Rev. 705 (2010); Biased, supra note 11, at 93; Cecilia L. Ridgeway \& Shelley J. Correll, Motherhood as a Status Characteristic, 60 J. SoC. Issues 683 (2004) [hereinafter Motherhood].

17. See Shelley J. Correll et al., Getting a Job: Is There a Motherhood Penalty?, 112 AM. J. SoC. 1297, 1298 (2007) [hereinafter Getting a Job]; Motherhood, supra note 16, at 684-85.

18. See generally Joni Hersch \& Leslie S. Stratton, Household Specialization and the Male Marriage Wage Premium, 54 INDUS. \& LAB. REL. REv. 78 (2000); Martha S. Hill, The 
receive a "mother penalty" 19 in compensation decisions. ${ }^{20}$ Research shows that married men earn higher wages than unmarried men. ${ }^{21}$ Audit studies or field experiments test employers' responses to mothers. Resumes are sent to employers that vary only on the parent status of the applicants in a subtle way. ${ }^{22}$ These studies reveal that women receive fewer employment offers, lower salary offers to similarly qualified women, and are less likely to be promoted when the resume has subtle indications that the female applicant is a mother. ${ }^{23}$ The same bias does not seem to operate for men or for women who are portrayed in the audit studies as not being mothers. ${ }^{24}$ Being a good father is not seen as incompatible with being an ideal worker. In fact, the research by Melissa Hodges and Michelle Budig suggests that there is a "daddy bonus." 25

The significance of parenthood status is underscored by research that finds that the pay gaps between mothers and nonmothers is larger

Wage Effects of Marital Status and Children, 14 J. HUM. RESOURCES 579 (1979); Melissa J. Hodges \& Michelle J. Budig, Who Gets the Daddy Bonus?: Organizational Hegemonic Masculinity and the Impact of Fatherhood on Earnings, 24 GENDER \& SOc'Y 717 (2010) [hereinafter Daddy Bonus]; Sanders Korenman \& David Neumark, Does Marriage Really Make Men More Productive?, 26 J. HUM. ResourCes 282 (1991); Eng Seng Loh, Productivity Differences and the Marriage Wage Premium for White Males, 31 J. HUM. RESOURCES 566 (1996).

19. See generally Heather Joshi \& Marie-Louise Newell, Pay Differentials and PARENTHOOD: ANALYSIS OF MEN AND WOMEN BORN IN 1946 (1989); Michelle J. Budig \& Paula England, The Wage Penalty for Motherhood, 66 AM. Soc. REv. 204 (2001); Amy J.C. Cuddy et al., When Professionals Become Mothers, Warmth Doesn't Cut the Ice, $60 \mathrm{~J}$. Soc. Issues 701 (2004); Jennifer Glass, Blessing or Curse? Work-Family Policies and Mother's Wage Growth Over Time, 31 WORK \& OCCUPATIONS 367 (2004); Shelly Lundberg \& Elaina Rose, The Effects of Sons and Daughters on Men's Labor Supply and Wages, 84 REv. ECON. \& STAT. 251 (2002); David Neumark \& Sanders Korenman, Sources of Bias in Women's Wage Equations: Results Using Siblings Data, 29 J. HUM. RESOURCES 379 (1994); Motherhood, supra note 16, at 684-85; Jane Waldfogel, The Effect of Children on Women's Wages, 62 AM. Soc. REv. 209 (1997); Jane Waldfogel, The Family Gap for Young Women in the United States and Britain: Can Maternity Leave Make a Difference?, 16 J. LAB. ECON. 505 (1998); Jane Waldfogel, Understanding the "Family Gap" in Pay for Women with Children, 12 J. ECON. PERSP. 137 (1998).

20. For evidence of motherhood penalties in wages, see Michelle J. Budig \& Paula England, The Wage Penalty for Motherhood, 66 AM. Soc. REv. 204 (2001). A recent review of the research on motherhood wage penalties is found in Margaret Gough \& Mary Noonan, A Review of the Motherhood Wage Penalty in the United States, 7(4) Sociology COMPASS 328-342 (2013).

21. Loh, supra note 18 , at 566.

22. See Getting a Job, supra note 17, at 1297 .

23. See id. at 1330.

24. See id. at 1298; Motherhood, supra note 16, at 697. See also MARY BLAIR-LoY, COMPETING Devotions: CAREER AND FAMILY AMONG WOMEN EXeCUTIVES (2003).

25. Daddy Bonus, supra note 18. 
than the gap between men and women. ${ }^{26}$ But to be clear, these stereotyped evaluations may persist absent empirical evidence of parenthood. Women may be disadvantaged based on the assumption that they may become mothers at some point. ${ }^{27}$

There is a growing body of research that finds that the motherhood penalty exists in more than a dozen countries in Europe and North America, ${ }^{28}$ including Australia, Canada, the United Kingdom, Germany, Finland, and Sweden. ${ }^{29}$ Researchers also find the motherhood penalty in studies of compensation from Austria, Germany, Italy, Luxembourg, Netherlands, Canada, Belgium, and France. ${ }^{30}$ Not only does it exist, but also it appears to be stable over time. ${ }^{31}$

Studies of the motherhood penalty have employed laboratory experiments, audit studies, ${ }^{32}$ and analysis of the longitudinal survey data, such as the National Longitudinal Study of Youth. ${ }^{33}$ All together, these studies consider the role of demographics and background credentials, family status, nature of the employment setting, and perceptions of performance evaluation in producing penalties for motherhood. Using survey data, Budig and Hodges were one of the first to consider a broad distribution of wages to assess whether size of earnings influences the motherhood penalty. ${ }^{34}$ Although they find significant motherhood penalties at all earnings levels, low

26. See generally Ann Crittenden, The Price of Motherhood: Why the Most IMPORTANT JOB IN THE WORLD IS STLL THE LEAST VALUED (2001) (examining the effect motherhood has on pay).

27. See Sticky Floors, supra note 1, at 71 (describing the assumption that women are "less committed to the practice of law because they have other responsibilities").

28. See, e.g., Stephen Benard \& Shelley J. Correll, Normative Discrimination and the Motherhood Penalty, 24 GENDER \& SOC'Y 616, 616 (2010).

29. See SuSAN HARKNESS \& JANE WALDFOGEL, CTR. FOR ANALYSIS OF SOC. EXClusion, The Family GaP in Pay: EvidenCe From Seven Industrialised CounTries, at iv (1999) (presenting research on the difference in hourly wages for women with and without children).

30. See Joya Misra et al., Employment, Wages, and Poverty: Reconciliation Policies and Gender Equity (Apr. 13, 2005) (unpublished paper), available at $\mathrm{http} / / / \mathrm{www}$. academia.edu/647485/Employment_Wages_and_Poverty_Reconciliation_Polici es_and_Gender_Equity (evaluating welfare state strategies and effects on the motherhood penalty).

31. See Sarah Avellar \& Pamela J. Smock, Has the Price of Motherhood Declined Over Time? A Cross-Cohort Comparison of the Motherhood Wage Penalty, 65 J. MARRIAGE \& FAM. 597 (2003) (discussing the gender gap across time).

32. See Motherhood, supra note 16, at 685; Getting a Job, supra note 17, at 1298, 1309.

33. See Budig \& England, supra note 19, at 204; Daddy Bonus, supra note 18, at 717 .

34. See Budig \& Hodges, supra note 16, at 705-06 (studying white women's earnings distribution). 
wage-earning women incur the largest penalties for being a mother. ${ }^{35}$ Most significantly, they find that the only female wage earners who do not experience a motherhood penalty are those women in the very highest wage category (90-95 th percentile). ${ }^{36}$ Although research consistently demonstrates that one-quarter to one-third of the wage penalty is attributed to human capital differences, ${ }^{37}$ only a few studies suggest that the motherhood penalty varies with skill level. ${ }^{38}$

Motherhood penalties have been linked to the number of children and timing of childbirth; Budig and Paula England found that the motherhood penalty increased with the birth of each additional child. ${ }^{39}$ The length of time out after the birth of a child is inversely related to income and advancement, even in countries as family friendly as Sweden. ${ }^{40}$ The relationship between motherhood penalties and mobility is mixed. Some research indicates that mobility after maternity may result in lower earnings; 41 remaining with the same employer can minimize the motherhood penalty. ${ }^{42}$ However, Budig and Hodges find that those who change jobs after maternity leave actually have smaller penalties than those who stay with the same employer. ${ }^{43}$

35. See id. See also Deborah J. Anderson et al., The Motherhood Wage Penalty Revisited: Experience, Heterogeneity, Work Effort, and Work-Schedule Flexibility, 56 INDUS. \& LAB. REL. REV. 273 (2003) (explaining the motherhood penalty in high school graduate mothers); Avellar \& Smock, supra note 31; Rebecca Glauber, Marriage and the Motherhood Wage Penalty among African Americans, Hispanics, and Whites, $69 \mathrm{~J}$. MARRIAGE \& FAM. 951 (2007) (explaining the "effects of race and marriage on the motherhood wage penalty").

36. See Budig \& Hodges, supra note 16 , at 721,724 .

37. See Budig \& England, supra note 19, at 214. See also Markus Gangl \& Andrea Ziefle, Motherhood, Labor Force Behavior, and Women's Careers: An Empirical Assessment of the Wage Penalty for Motherhood in Britain, Germany, and the United States, 46 DEMOGRAPHY 341 (2009).

38. See David Ellwood et al., The Mommy Track Divides: The Impact of Childbearing on Wages of Women of Differing SkILl Levels (2004) (finding that women with higher skill levels are more greatly affected by the motherhood wage penalty, which contradicts previous studies).

39. Budig \& England, supra note 19, at 217.

40. See Silke Aisenbrey et al., Is There a Career Penalty for Mothers' Time Out? A Comparison of Germany, Sweden and the United States, 88 Soc. ForCes 573 (2009) (finding career penalties for both short-term and long-term breaks in the United States and a penalty in Germany that increases with the time of the break).

41. See, e.g., Sylvia Fuller, Job Mobility and Wage Trajectories for Men and Women in the United States, 73 AM. Soc. REv. 158 (2008).

42. See Gangl \& Ziefle, supra note 37 , at 347.

43. Budig \& Hodges, supra note 16 , at 720 . 
Other factors influencing motherhood penalties that have been asserted but not confirmed empirically include the timing of children ${ }^{44}$ and the significance of family friendly policies. ${ }^{45}$ Finally, many scholars argue that women, with and without children, will never live up to expectations of the "ideal worker." 46

\section{RESEARCH QUESTION}

What is the relationship between parenthood status and lawyer compensation? Since the $A J D$ survey is limited to lawyers in a specific cohort, it offers a unique perspective on this question. The sample closely approximates the distribution of lawyers across firm, government, and business employers. The gender composition closely matches data published by the American Bar Association. ${ }^{47}$

Most studies of motherhood penalties isolate their focus on the comparison of mothers and nonmothers ${ }^{48}$ or the comparison of fathers and nonfathers. ${ }^{49}$ Very few have joined the four parenthood categories (mothers/fathers and nonmothers/nonfathers) as we do below. Unlike much of the existing research where the small number of minority respondents does not allow researchers to assess the effect of minority status, we are able to explore the relationship between race and parenthood. We begin our analysis by examining the relationship between parenthood and a range of independent variables, which were previously identified as factors that influence compensation decisions. These include the demographics and credentials that lawyers bring to their practice, the organizational settings where lawyers work, the lawyers' orientations to work and satisfaction, and the indicators of performance. The second part of the analysis looks specifically at the relationship between compensation and parenthood.

44. See Hiromi Taniguchi, The Timing of Childbearing and Women's Wages, $61 \mathrm{~J}$. MARRIAGE \& FAM. 1008 (1999) (asserting that women who postpone motherhood may incur a zero to minimal wage penalty).

45. See Glass, supra note 19 , at 380.

46. See generally UNBENDING GENDER, supra note 9.

47. ABA, Section on Legal Education, First Year Enrollment in ABA Approved Law Schools 1947.2004 (Percentage of Women) (2005), available at http://www.abanet.org/ legaled/statistics/femstats.html.

48. Budig \& England, supra note 19, at 204.

49. See generally Hodges \& Budig, supra note 16. 


\section{DATA AND MEASURES}

\section{A. After the JD Study}

The research that serves as the basis for this paper is from the second wave of data from the $A J D$ study. ${ }^{50}$ This is the first national longitudinal survey of law graduates in the United States. ${ }^{51}$ The sample is representative of the national population of lawyers who were admitted to the bar in 2000 and graduated from law school June 1998 through July 2000.52 The sampling design used a two-stage process. "In the first stage, the nation was divided into eighteen strata by region and size of the new lawyer population." 53 "Within each stratum, one primary sampling unit (PSU) - metropolitan area, portion of a state outside large metropolitan areas, or entire state-was chosen." "The PSUs included all four major markets, those with more than 2,000 new lawyers (Chicago, Los Angeles, New York, and Washington, DC); five of the nine large markets, those with 750 to 2,000 new lawyers [(Boston, Atlanta, Houston, Minneapolis, and San Francisco)]; and nine of the remaining, smaller markets [(Connecticut, New Jersey remainder, Florida remainder, Tennessee, Oklahoma, Indiana, St. Louis, Utah, and Oregon)]." "In "In the second stage, ... individuals [were sampled] from each of the PSUs at rates that would, combined, generalize to the national population." 56 In addition, the study included an "oversample of 1,465 new lawyers from minority groups (black, Hispanic, and Asian)." ${ }^{57}$ "The final sample included 9,192 lawyers in the eighteen PSUs."58 The first wave (AJD1) data collection relied on a mail questionnaire fielded in May 2002.59 Researchers followed up with nonrespondents by mail and phone, with the telephone using a somewhat abridged version of the mail questionnaire. During the first wave, of the sample members "who were located and who met the criteria for inclusion in the study, 71

50. AJD2, supra note 3.

51. RONIT DINOVITZER ET AL., AFTER THE JD: FIRST RESULTS OF A NATIONAL StUdY OF LEGAL CAREERS 13 (2004) [hereinafter AJD1].

52. AJD2, supra note 3 , at 12 .

53. AJD1, supra note 51 , at 89.

54. Id.

55. Id.

56. Id.

57. Id. The sample also included respondents who self-identified as Native Americans, however the number of respondents in this category is too small for the present analysis. Id. at 67.

58. Id. at 89 .

59. Id. 
percent responded either to the mail questionnaire or to a telephone interview for a total of 4,538 valid responses." 60

A second wave of $A J D$ (AJD2) was designed to locate and survey the entire original sample constructed in AJD1 and to trace the career progression after approximately seven years in practice. The locating process was extensive and included searching for those in the original AJD1 sample who had not been located or who had not responded. ${ }^{61} \mathrm{~A}$ total of 70.4 percent of the AJD2 respondents had previously responded. ${ }^{62}$ Our paper focuses on the 2,890 respondents who completed both AJD1 and AJD2 questionnaires $(\mathrm{N}=2890)$.

\section{B. Measures}

\section{Compensation}

Since we focus on the earnings of lawyers as professionals, we adopt a measure of compensation that includes three components: salary, bonus, and profit sharing-all measured on an annual basis. Our measure of compensation is based on self-reported lawyers' annual earnings at the time of the second wave survey. As is common practice, our analyses rely on the natural $\log$ of compensation to reduce heteroskedasticity. ${ }^{63}$

\section{Parenthood}

While many of the $A J D$ respondents had become parents, slightly less than half were without children when they were surveyed in 2007.64 To examine the effect of parenthood status, we created four distinct parenthood groups to reflect that not having a child is a parenthood status too. Our parenthood statuses included: Mothers, Fathers, Women Without Children (WWC), and Men Without Children (MWC).

\section{Components of Law Practice}

Our goal is to understand how parenthood affects lawyers' practice methods and the compensation they earn. We include a range of factors

60. Id. at 90 .

61. AJD2, supra note 3 , at 12 .

62. Id.

63. Heteroskedasticity describes a data sample or data-generating process in which the variances in the population distribution differ for the values of the independent variables. See DAVID KNOKE \& GEORGE W. BohrnstedT, BASIC Social STATISTICS (1991).

64. Id. at 69 . 
related to law practice that our first wave analysis of compensation revealed as important to understanding compensation. These include demographics, previous experience, and work structures. ${ }^{65}$ To these factors we added lawyers' orientation to work and performance indicators. Since many of our respondents changed jobs between the two waves of the survey, we were interested in what factors mattered most to them as they made a decision to accept their current position. With longer tenure in the profession, performance measures begin to matter more.

\section{a. Demographics}

We include a range of demographic characteristics-including race, age, and marital status-that prior research indicates have important relationships with compensation. The ages of respondents are their actual ages as of 2007 .

\section{b. Previous Experience}

These variables measure the effect of both law school background and type of practice setting from the first wave. We include the credentials from law school, both self-reported law school GPA and a variable reflecting law school rank. For law school rank, we created a dummy variable to measure whether respondents attended an elite law school, operationalized as a top twenty law school.66 A third variable captures the accumulated human and social capital from working in a firm with more than 100 lawyers. ${ }^{67}$

\section{c. Orientation to Work}

To capture the respondents' orientation to work, we measure factors that were important in job selection and satisfaction with current employment. We introduce three independent variables that reflect respondents' orientation to their current employment. A factor analysis of second wave responses to questions about the importance of factors in their decision to take on their current position uncovered two clusters that we call Career and Lifestyle. Career is a composite measure

65. See Dinovitzer, et al., supra note 1, at 826-27.

66. See id. at 830 . We follow the 2003 U.S. News \& World Report rankings.

67. See generally Ronit Dinovitzer, The Financial Rewards of Elite Status in the Legal Profession, 36 LAW \& SOC. INQUIRY 971 (2011) (finding that "inherited cultural capital produces an earnings advantage as soon as lawyers begin their careers and that this gap persists over time"). 
compiled from the responses to how important the following items were to respondents' decisions to assume their current job: salary, benefits, prospects for advancement, prestige of the organization, diversity of the workplace, and opportunity to develop specific skills. We recognize that these reflect attention to the career development potential of their employment.

The second composite measure focused on the importance of what we describe as lifestyle factors. This composite measure focuses on office environment/collegiality, hours expected, location, potential to balance work and personal life, opportunity to do socially responsible work, and match of employer's mission with the lawyer's mission. We calculated each of the composite measures by totaling the Likert scale scores and then calculating a mean for each respondent. These measures are scored from low (not important $=1$ ) to high (very important $=7$ ). Based on a factor analysis of the sixteen measures collected on job satisfaction, we employ three dimensions of satisfaction that emerged from the first wave analysis: 68 The first dimension, "job setting satisfaction," includes recognition received at work, relationships with colleagues, control over the work, and job security. The second dimension, "work substance satisfaction," reflects the intrinsic interest of the work. Finally, the third dimension, "power track satisfaction," is composed of two items: satisfaction with compensation levels and satisfaction with opportunities for advancement.

\section{d. Structure of Work}

The structure of work introduces a series of dummy variables to represent the type of practice setting where respondents were employed after seven years of practice. Our measures of practice setting rely on the size of respondents' entire firm rather than the local office in which they work. This selection of firm size was chosen because salaries are driven by the national scale of a firm rather than by its local position. Following our previous analysis of AJD1 income inequality, dummy variables were introduced for solo practice, small firms (2-20 lawyers), medium firms (21-100 lawyers), large firms (101-250 lawyers), and mega firms (over 250 lawyers). Because of the shifts out of private firm practice, we introduced dummy variables for business, nonprofit, and government practice. As market was an important predictor in the analysis of AJD1 data, we introduced two dummy variables to reflect the size of the labor market in which respondents are located. These

68. See Ronit Dinovitzer \& Bryant Garth, Lawyer Satisfaction in the Process of Structuring Legal Careers, 41 LAW \& SoC'Y REV. 1, 10 (2007). 
markets are the mega markets and large markets. The categories correspond with the original sampling design that reflects the number of lawyers admitted per year within the markets. The mega market refers to geographical locations where more than 2,000 lawyers are admitted per year. Large markets are those admitting between 750 and 2,000 lawyers per year. Because of the dispersal of lawyers between the survey times, we found it nearly impossible to identify midrange markets with any accuracy.

\section{e. Performance}

Finally, we introduced three variables to reflect effort and performance of these lawyers in their workplaces. The first reflects the types of clients represented in the respondents' current job. We created a dummy variable, clients, to reflect lawyers who spend 25 percent or more of their time representing high-income individuals, Fortune 500 businesses, or other large or middle-sized businesses. Thirty-one percent of our respondents represent these high profile parties at least 25 percent of the time. We include two measures of work effort: the log of total hours worked last week and the billable hours reported for the preceding year.

\section{METHODOLOGY}

To examine the relationship between parenthood status and the key variables identified as important predictors of income, we used Analysis of Variance (ANOVA). ${ }^{69}$ ANOVA is a statistical measure that tests whether there are any significant differences in the means of three or more independent groups. ${ }^{70} \mathrm{~A}$ finding of significant difference indicates that we have confidence that the differences that we observe in the data reflect a pattern and have not occurred by chance. The ANOVA procedure requires that the variances in our predictors of income are equal among groups. This was the case for some, but not all, of the variables we analyzed. When that statistical requirement was not met, we used the Kruskal-Wallis equality of populations rank test to adjust for the violation of equal variances and to confirm/disconfirm our findings of difference.

69. For a model predicting income during Wave 1, see Dinovitzer et al., supra note 1.

70. Researchers employed the software package of STATA to calculate the Analysis of Variance. In addition, Bonferroni tests were calculated and are reported in the tables. Statistical significance is reported as "p-values" that measure the confidence that the observations are not the result of chance. We assume statistical significance when we have $95 \%$ confidence in our results, i.e., p-values that are less than .05 . 
While the ANOVA test provides valuable information that groups differ, it does not provide information about the specifics of those differences. As we see below, the ANOVA analysis tells us that parenthood produces a significant effect on compensation. However, the ANOVA does not tell us where that effect occurs. The significant difference could be between any or all of the different parenthood statuses. To determine where the significant differences between parenthood statuses are found and to unravel some of the interaction between gender and parenthood, we conducted a Bonferroni test that allows us to identify which of the different parenthood statuses matter most, if at all. Unless otherwise stated, the " $p$ " values reported in the text refer to the Bonferroni test of differences.

\section{PARENTHOOD AND ItS EFFECT ON FACTORS THAT PREDICT COMPENSATION}

The first set of analyses seeks to examine how parenthood status matters to the key variables previously identified as important to understanding compensation.

\section{A. Demographics}

Not surprisingly, lawyers with children were more likely to be married than lawyers without children. Given the cohort design of our sample, age was not related to parenthood status. However, interestingly, we find a significant relationship between parenthood status and minority status $(p<.000)$. Because minority status is coded as zero (white) or one (nonwhite), the means in Table One need to be interpreted as how close or far they are from zero or one.

Table 1: Minority Status and Parenthood-Full-Time Lawyers

\begin{tabular}{llll}
\hline & Mean & SD & Freq \\
\hline Mothers & .26 & .44 & 522 \\
Fathers & .23 & .42 & 816 \\
Women Without Children & .38 & .49 & 520 \\
Men Without Children & .36 & .48 & 619 \\
\hline
\end{tabular}

$\mathrm{F}=16.79, p=.000 ;$ Kruskal-Wallis Chi-Squared: 75.25 with $3 \mathrm{df}$, $p=.0001$

The mean values of lawyers who did not have children were closer to the value associated with minority status (mean for $\mathrm{WWC}=.38$ and mean for MWC $=.36$ ) than those who are parents $(p<.003)$. The 
significant relationship between minority status and parenting status suggests that minority lawyers may choose to delay parenthood or not be parents at all, perhaps to avoid an additional complication to what previous research suggests is an already complicated relationship for minorities in law. ${ }^{71}$

\section{B. Previous Experience}

Parenthood does not appear related to previous experience, with one surprising exception: a small difference in law school grade point average $(p<.04)$. Here, the only difference between groups that is statistically significant is the difference between fathers and men without children; men without children had lower law school grades than their counterparts who were fathers $(p<.025)$.

\section{Orientation to Work}

We find differences by parenthood status in the career orientation that lawyers bring to their job, although the main effect is limited to the differences between men and women. Men without children were less oriented to the career development aspects of their jobs than women without children. While there is no difference between mothers' and fathers' career orientation, for those without children, gender matters. Women without children were more focused on their career development than men without children.

Not surprisingly, we find a relationship between parenthood status and the significance of lifestyle factors in the decision to take on current positions. Table Two presents the mean values of the importance of lifestyle factors, scored from one (not important) to seven (very important).

71. See David B. Wilkins, From "Separate is Inherently Unequal" to "Diversity is Good for Business": The Rise of Market-Based Diversity Arguments and the Fate of the Black Corporate Bar, 117 HARV. L. REV. 1548, 1589-90 (2004) (detailing the complicated relationship between minority lawyers and law firms). See generally David B. Wilkins \& G. Mitu Gulati, Why Are There So Few Black Lawyers in Corporate Law Firms?: An Institutional Analysis, 84 CALIF. L. REV. 493, 526-27 (1996) (examining "the institutional factors that tend to perpetuate the existing underrepresentation" of black lawyers in large corporate firms). 
Table 2: The Importance of Lifestyle and Parenthood StatusFull-Time

\begin{tabular}{llll}
\hline & Mean & SD & Freq \\
\hline Mothers & 5.02 & 1.16 & 431 \\
Fathers & 4.57 & 1.16 & 626 \\
Women Without Children & 4.89 & 1.19 & 443 \\
Men Without Children & 4.52 & 1.20 & 469 \\
\hline
\end{tabular}

$\mathrm{F}=20.48, p=.001$

Most significantly, gender, not motherhood, explains the different group effects. Mothers and women without children rated lifestyle factors as more important to their decisions to take on their current jobs than fathers or men without children $(p<.001)$. Even so, the relative mean values (five out of a seven point scale) suggest that lifestyle is only somewhat important to how lawyers decide about job opportunities.

\section{Structure of Work}

Parents and nonparents are differently distributed across practice settings. Table Three presents the percentage of lawyers within each parenthood status that work in the different practice contexts. Separate ANOVA analysis of practice settings by parenthood status reveals that parenthood status does not have a statistically significant effect on where one practices with the exception of the nonprofit sector. Women, both mothers and women without children, were more likely to be found practicing in nonprofit sectors than their male counterparts. 
Table 3: The Distribution of Parenthood Status Across Practice Setting-Full-Time

\begin{tabular}{|l|l|l|l|l|}
\hline & Mothers & Fathers & $\begin{array}{l}\text { Women w/o } \\
\text { Children }\end{array}$ & $\begin{array}{l}\text { Men w/o } \\
\text { Children }\end{array}$ \\
\hline Solo & $6.0 \%$ & $8.3 \%$ & $5.3 \%$ & $10.6 \%$ \\
\hline Firm, 2-20 & $16.4 \%$ & $20.6 \%$ & $16.7 \%$ & $19.5 \%$ \\
\hline Firm, 21-100 & $9.5 \%$ & $10.4 \%$ & $8.9 \%$ & $11.6 \%$ \\
\hline Firm, 101-250 & $3.9 \%$ & $6.0 \%$ & $5.9 \%$ & $4.8 \%$ \\
\hline Firm 251+ & $13.2 \%$ & $15.8 \%$ & $10.8 \%$ & $13.5 \%$ \\
\hline Government & $27.6 \%$ & $16.7 \%$ & $27.4 \%$ & $17.2 \%$ \\
\hline Nonprofit & $6.0 \%$ & $3.5 \%$ & $6.7 \%$ & $3.4 \%$ \\
\hline Business & $17.4 \%$ & $18.6 \%$ & $18.2 \%$ & $19.3 \%$ \\
\hline $\begin{array}{l}\text { Total } \\
\text { N= }\end{array}$ & 517 & 778 & 492 & 584 \\
\hline
\end{tabular}

Pearson Chi Square $=74.4901, \mathrm{p}=.000$

Parenthood is associated with whether a lawyer practices in one of the mega markets $(\mathrm{F}=10.23, p<.000)$. The group effect that matters here is only evident for women without children who demonstrated a greater tendency than mothers or fathers to practice in large markets $(p<.000)$.

\section{E. Performance}

Parenthood status has an effect on experience working with high profile clients $(F=4.89, p<.002)$. Fathers had more experience working with high profile clients than either mothers or women without children. There is no statistical difference between fathers and men without children with respect to how often they worked with high profile clients. This is consistent with men having more opportunities to engage in work that yields larger rewards. 
We find that parenthood status affects reported hours worked last week $(\mathrm{F}=16.4, p<.000)$, but as others have shown, it is gender that matters more. Regardless of whether they were parents, women reported working fewer hours than men $(p<.001)$. However, when examining the number of billable hours reported for the preceding year, ${ }^{72}$ we find important differences by parenthood status (Table Four), specifically in the different effects between mothers and women without children $(p<.036)$ and between mothers and fathers $(p<.001)$.

\section{Table 4: Parenthood Status and Billable Hours}

\begin{tabular}{llll}
\hline & Mean & SD & Freq \\
\hline Mothers & 1725 & 459 & 191 \\
Fathers & 1879 & 447 & 385 \\
Women Without Childrer & 1833 & 430 & 184 \\
Men Without Children & 1841 & 454 & 283 \\
\hline
\end{tabular}

$\mathrm{F}=5.05, p=.002$

\section{PARENTHOOD AND COMPENSATION}

The comparison of mean compensation by parenthood status in Table Five demonstrates the significant effects of gender regardless of parenthood status on overall compensation. Fathers earn more than mothers $(p<.000)$ and women without children $(p<.000)$. Men without children earn more than women regardless of whether the woman has a child or not $(p<.002)$.

Table 5: Compensation and Parenthood Status-Full-Time Employment

\begin{tabular}{llll}
\hline & Mean & SD & Freq \\
\hline Mothers & 112093 & 71408 & 453 \\
Fathers & 140988 & 87175 & 726 \\
Women Without Children & 110491 & 62404 & 442 \\
Men Without Children & 130199 & 78354 & 518 \\
\hline
\end{tabular}

$\mathrm{F}=20.55, p=.000 ;$ Kruskal-Wallis, Chi-squared $=78.50$, with $\mathrm{df}=2$

Further analysis of compensation within particular practice settings revealed few settings where parenthood status had an effect on compensation. The two exceptions were business and small-firm practice. In business, we found a tendency toward a fatherhood

72. Of course, this measure is significant only to those contexts where billable hours are part of the evaluation. 
premium. ${ }^{73}$ Fathers reported significantly higher compensation than mothers $(p<.027)$ and women without children $(p<.013)$. The compensation advantage of fathers over men without children is present but not statistically significant. In small firms we observe a tendency toward a motherhood penalty. ${ }^{74}$

\section{DISCUSSION/CONCLUSION}

We did not find that parenthood status had a significant effect on credentials, orientation to work, or even to where lawyers actually practice law. In the few instances where we did find an overall effect of parenthood status, our more in-depth analyses demonstrate that gender matters more. The primary effect for gender rather than parenthood status may be an artifact of the career and family stages of our respondents. If motherhood penalties accumulate as women bear more children, as some research suggests, we may find a stronger effect for motherhood in the next wave of $A J D$.

A few anomalies require more analysis. When compared to men who do not have children, women who are childless find career development factors more important to their decisions to accept their current positions. Women seem to be thinking more strategically than their male counterparts. Why is that?

The motherhood effect we find for billable hours is not found in our analysis of reported hours worked. Gender appears to matter more to reported hours than to whether one is a mother. The different effects that motherhood has on the hours lawyers work and on billable hours is an important anomaly that requires more analysis. Do mothers have fewer opportunities to accumulate billable hours than women without children and men? If mothers have fewer opportunities for billing hours compared to women without children, can motherhood stereotyping explain that outcome? This would certainly be consistent with status-expectations theory.

In sum, we do not find the motherhood penalty or fatherhood premium in compensation that has been the subject of intense scholarly interest over the past decade. In the professional context of law, gender matters more. It may well be that motherhood and fatherhood effects are so well embedded in cultural schemas that empirical field research, as opposed to social experiments, cannot reveal them. As the papers in

73. ANOVA results for the effect of parenthood status on compensation in business: $\mathrm{F}=3.36, \mathrm{p} .<.02$. See Daddy Bonus, supra note 18 (providing additional evidence about the fatherhood advantage).

74. ANOVA results for the effect of parenthood on compensation in small firms: $\mathrm{F}=6.01, \mathrm{p} .<.001$. 
this special issue show, the challenges to empirical measurement of subtle (normative) discrimination are even greater when working across cultures. 